\title{
『ジオメンブレンの応力緩和特性に関する研究』
}

\author{
宇都宮大学工学研究科坪井正行 \\ 宇都宮大学工学部泉繁良 \\ 東洋ゴム工業（株）＼cjkstart宮地秀樹
}

廃棄物最終処分場に設置されたジオメンブレンに作用する応力やひずみを解明することはジオメンブレ ンの設計上非常に重要なことばかりでなく、シート端部に伝達されるので、シート固定工の設計にも大変 重要である。本研究は、ジオメンブレンの応力緩和及び応力緩和を受けた HDPE シート、FPA シート、EPDM シートの引張特性について実験的に研究し、一度除荷した場合の弾性係数について報告する。実験結果よ り、応力はジオメンブレンの種類によって緩和の傾向が異なるが、時間の対数と直線的な関係を示した。 応力緩和後の応力ひずみ曲線から、設計手法で用いられる $1 \%$ 弾性係数を求めると、緩和傾向は示すもの の応力緩和を受ける前の弾性係数にほぼ匹敵し、HDPE シートではひずみが約 $20 \%$ で曲線が一致してい る。これらから、設計上ジオメンブレンの応力を求める場合で、ひずみが断続的または継続的に増加する 場合には応力の緩和を見込むと危険であると言える。

\section{Study on Mechanical Properties of Geomembrane after Creep}
M. TSUBOI
Utsunomiya University
S. IMAIZUMI
Utsunomiya University
H. MIYAJI Toyo Tire and Rubber co.,ltd.

It is very important for aiding a safety designing with geomembrane to know stress and strain of the geomembrane installed on the ground of landfill. The relaxation test with constant strain and tensile test with the specimen after creep test had been conducted. After comparison of the stress-strain curve after and before relaxation test at $5 \%$ strain, the secant modulus obtained from curves are almost the same. So, when the stress of geomembrane is used for designing under the strain increasing condition, the decreasing of stress by relaxation must not be included in the stress calculation of stress. 


\title{
『ジオメンブレンの応力緩和特性に関する研究』
}

\author{
宇都宮大学工学研究科 ○坪井正行 \\ 宇都宮大学工学部泉繁良 \\ 東洋ゴム工業（株）＼cjkstart宮地秀樹
}

\section{1.まえがき}

廃棄物最終処分場には、ごみや焼却灰から発生する浸出水（污水）の地下水への浸透を防ぐ目的で、表 面しゃ水エとして、ジオメンブレンが用いられている。廃棄物処分場の法面に設置されたしゃ水シートに は自重や低温時の収縮力（熱応力）、地盤沈下による引張等によってジオメンブレンには応力及びひずみ が発生する。 L S プロジェクト報告書 ${ }^{1)}$ によば、高さ $5 \mathrm{~m}$ の法面に設置されたジオメンブレンが埋立て による引き込み力を受ける時に HDPE シートでは最大応力 $3.0 \mathrm{MPa}$ が発生し、0．7.0MPa が残留し、EPDM シートでは最大応力 $0.072 \mathrm{MPa}$ が発生し、0.46 MPa が残留すると報告している。また、鈴木ら ${ }^{2)}$ は塩化ビニル製ジオメンブレンの伸び率 $100 \%$ における応力変化を計測し、約 10 時間後の応力が $1 /$ 4 にまで緩和すると報告している。

ジオメンブレンに作用する応力やひずみを解明することはジオメンブレンの設計上非常に重要なことば かりでなく、シート端部に伝達されるので、シート固定工の設計にも大変重要である。

ジオメンブレンは合成樹脂や合成ゴムを主成分としているが、これら高分子化合物は土木材料の中では 比較的小さな応力で弾性及び塑性变形を生じるという特徵を持つ。このために、ジオメンブレンは一定の ひずみを与えられた状態で放置されると時間とともに応力緩和を生じる。したがって圧密による地盤沈下 に伴う斜面長の変化などによってジオメンブレンに生じるひずみ及び応力は、長期間を要して徐々に増加 するものであることから、 50 ～ $500 \mathrm{~mm} / \mathrm{min}$ の速度で通常実施されている引張試験から求められる応 力一ひずみ曲線に比較すると、応力が小さくなることが予想される。このために、ジオメンブレンを用い た設計において、応力緩和を考慮することで過剩な固定工の設計等を避けることができるものといえる。 しかしながら、ジオメンブレンの応力緩和及びその影響についての研究例は少ない。

本研究は、ジオメンブレンの応力緩和及び応力緩和を受けたジオメンブレンの引張特性について実験的 に研究し、設計手法における応力緩和に関する提案を行うことを目的とした。

\section{2. 応力緩和について}

\section{1 試験方法}

代表的なジオメンブレンに一定のひずみを与えた状態で放置した時の応力の変化を求めた。試験方法とし ては図 1 に示す応力緩和試験装置を作成し試験片を取り付けた。応力緩和試験装置は試験片を取り付ける クランプとクランプ移動ネジ、フレーム及び荷重計とから構成される。試験片は代表的なジオメンブレン とし、JIS K6215 に規定される 1 号ダンベル（幅 $10 \mathrm{~mm}$ 、標線間距離は $40 \mathrm{~mm}$ ）を用いた。試験片に 
標線をマーキングした後にクランプにネジ締めにて取り付け、概ね $50 \mathrm{~mm} /$ 分の速度で引張り、標線間距 離が所定の長さとなったところで固定した。荷重の計測は荷重計をデータロガーに接続して記録した。遮 水シートは厚さが $1.5 \mathrm{~mm}$ の HDPE シート、EPDM シート、FPA シートの 3 種類とし、ひずみレベルは、 $5 \%$ 、 $10 \% 、 20 \% 、 30 \%$ 及び $50 \%$ 種類とした。

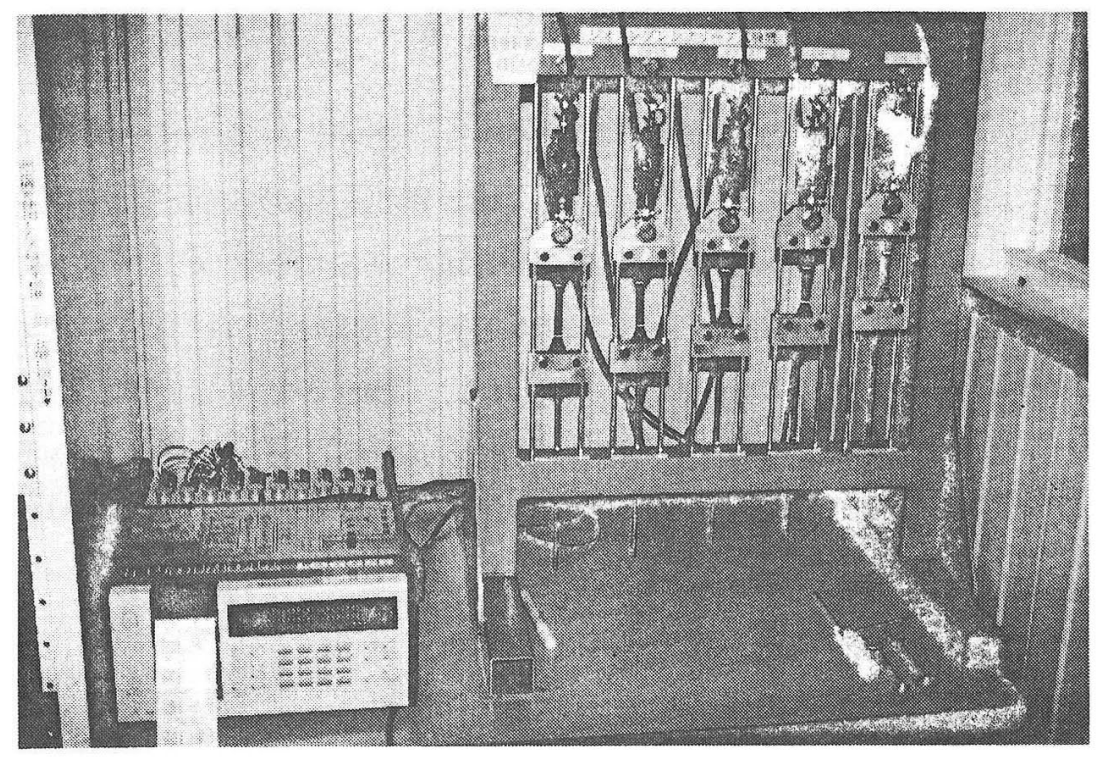

図1 応力緩和実験状況

\section{2 試験結果}

経過時間と応力の関係について、HDPE シートについて図 2 に、EPDM シートについて図 3 に、FPA シー トについて図 4 に、横軸を時間の対数とした図を並べて示す。
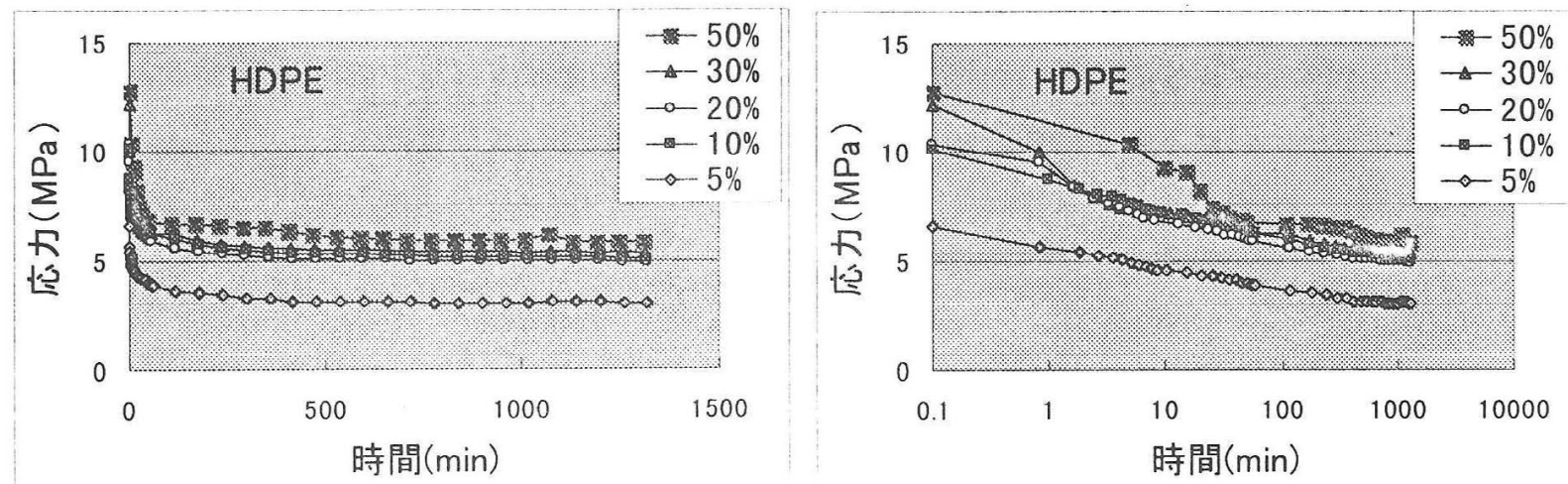

図2 HDPE シ一トの応力緩和試験結果 

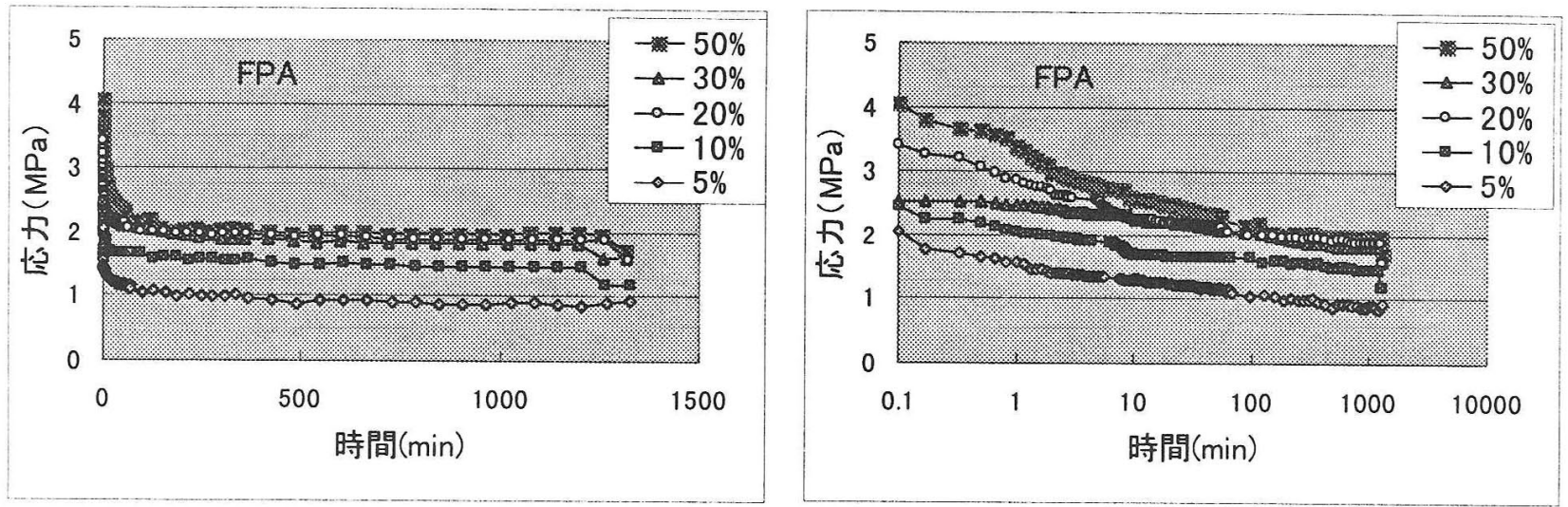

図3 FPA シートの応力緩和実験結果
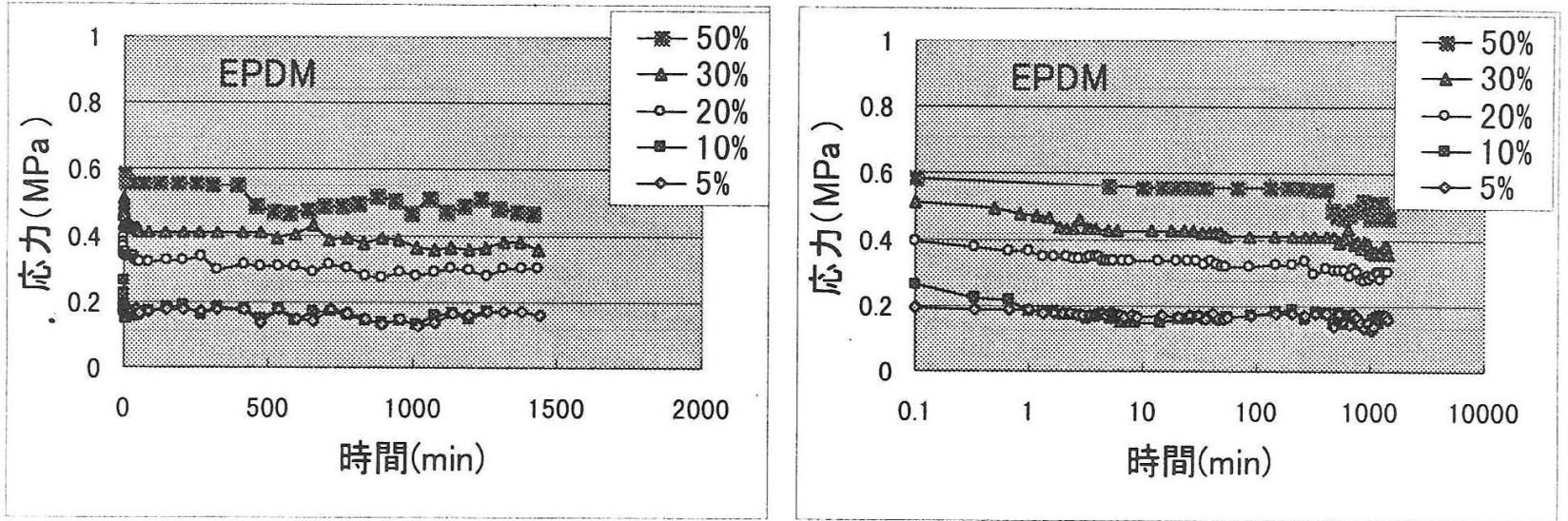

図4 EPDM シートの応力緩和実験結果

応力が緩和する傾向は 3 種類の遮水シートで見られる。緩和の傾向は時間を対数としたグラフでより明 確に表わされる。 $5 \%$ 及び $10 \%$ の場合について、時間 t $(\min )$ と応力 $\sigma(\mathrm{MPa})$ との関係を近似曲線を 式（1）～式（6）に示す。

$\begin{array}{lllll}\text { HDPE シート } & 5 \% & \sigma_{(\mathrm{t})}=-0.51 \log (\mathrm{t})+8.5 & \text { (1) 式 } \\ & 10 \% & \sigma_{(\mathrm{t})}=-0.37 \log (\mathrm{t})+5.5 & \text { (2)式 } \\ \text { FPA シート } & 5 \% & \sigma_{(\mathrm{t})}=-0.089 \log (\mathrm{t})+2.0 & \text { (3)式 } \\ & 10 \% & \sigma_{(\mathrm{t})}=-0.096 \log (\mathrm{t})+1.5 & (4) \text { 式 } \\ \text { EPDM シート } & 5 \% & \sigma_{(\mathrm{t})}=-0.0033 \log (\mathrm{t})+0.18 & (5) \text { 式 } \\ & 10 \% & \sigma_{(\mathrm{t})}=-0.0043 \log (t)+0.18 & (6) \text { 式 }\end{array}$


図 2 図 4 より、ジオメンブレンの応力と時間の対数との関係は直線的であることがわかる。また、応 力緩和の状況を示す直線の勾配はジオメンブレンの種類によって大幅に異なることがわかる。すなわち、 HDPE シートでは応力緩和の傾向が大きく、EPDM シートではこの傾向が小さいといえる。応力緩和の傾向 が大きい HDPE シートでは 24 時間後には初期応力の半分以下にまで低下している。

\section{3. 応力緩和後の応カひずみ曲線について}

\section{1 試験方法}

所定のひずみを与えた状態で 24 時間放置した後に、ひずみを開放して供試体を取り外し、再び、引張 試験機に取り付けて、ゆっくりと所定のひすみにまでチャック間距離を調製した後に、引張試験を実施し た。供試体にはあらかじめ幅 $40 \mathrm{~mm}$ の標線を設けておき、標線間距離でひずみを計測した。引張速度は ゆっくりとした速度として $1 \mathrm{~mm} / \mathrm{min}$ とした。

\section{2 試験結果と考察}

応力緩和後の応力ひずみ曲線を HDPE シートについて図 5 に、FPA シートについて図 6 に、EPDM シート に図 7 に示す。

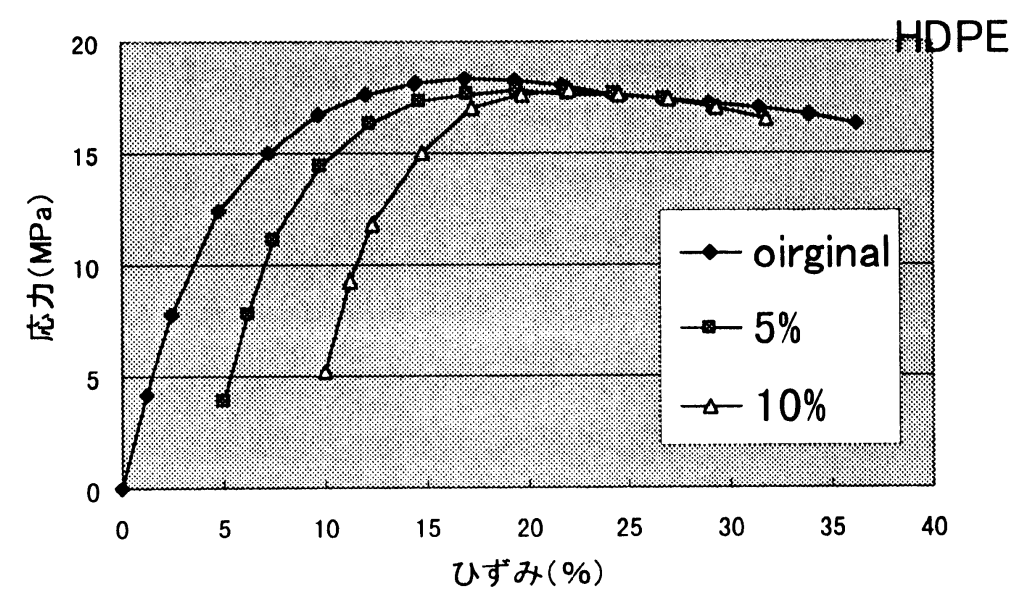

図5 HDPE シートの応カひず曲線(応力緩和後) 


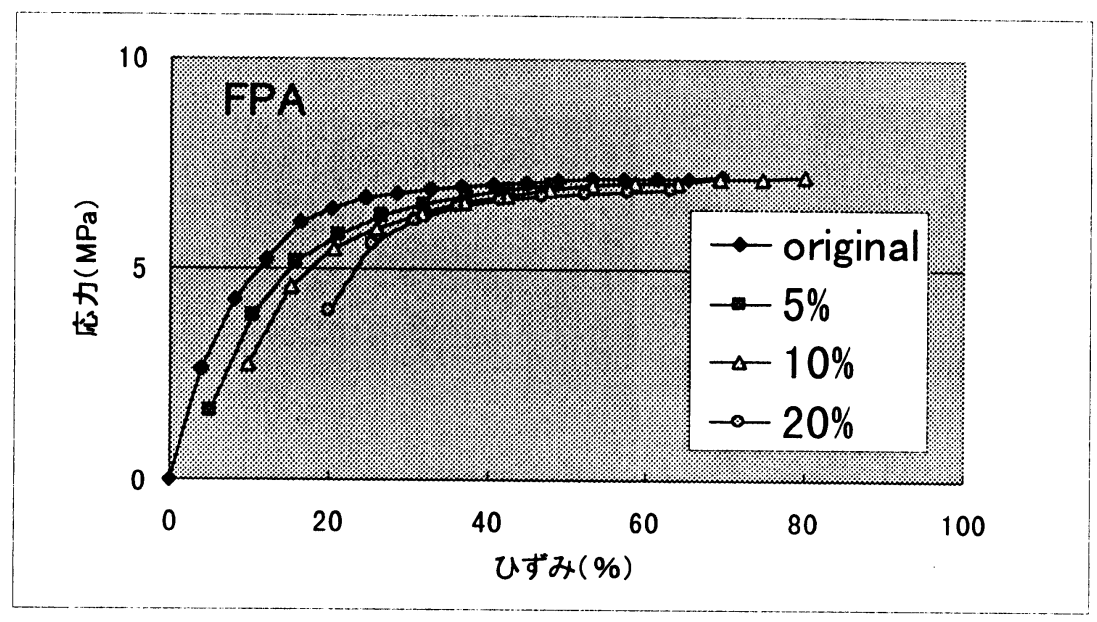

図6 FPA シートの応カひず曲線(応力緩和後)

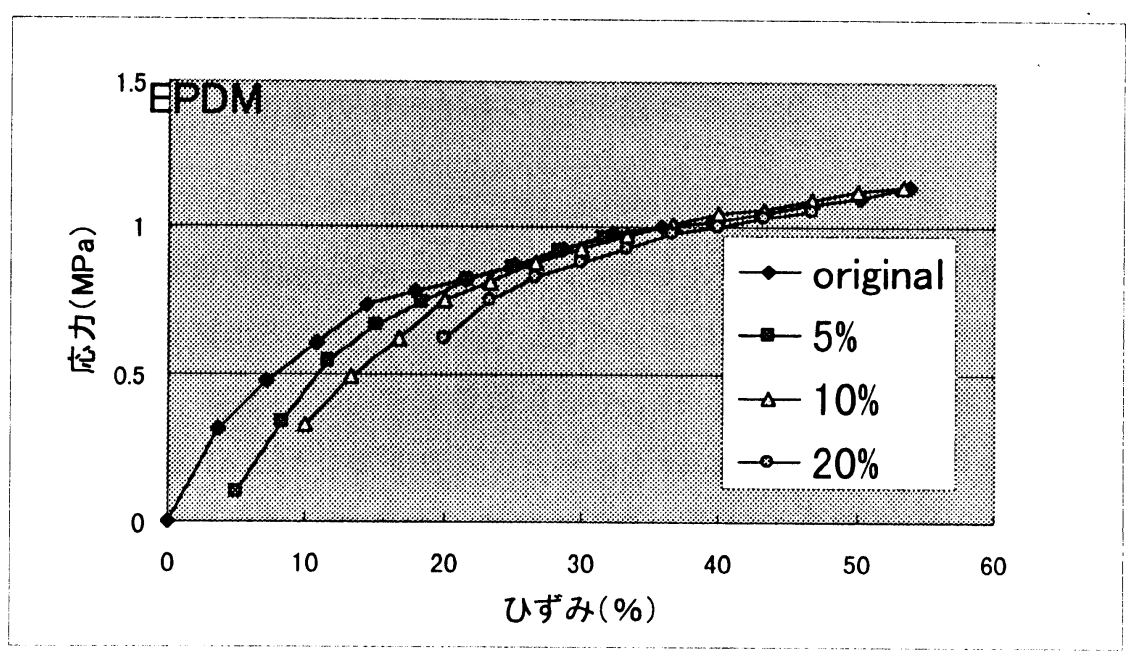

図7 EPDM シートの応カひず曲線(応力緩和後)

応力緩和試験後の応力ひずみ曲線は、Aに示す応力 緩和を生じ、その後の応力ひずみ曲線は、B に示す形 状を示している。即ち、Cに示すようなオリジナル曲 線を平行に移動した形状ではなく、傾きが大きくなる。

図 9 にオリジナルの弾性係数と応力緩和後の弾性系 数を示す。オリジナルの弾性係数は横軸のひずみがゼ ロに示し、弾性係数は 1 \%割線弾性係数とした。

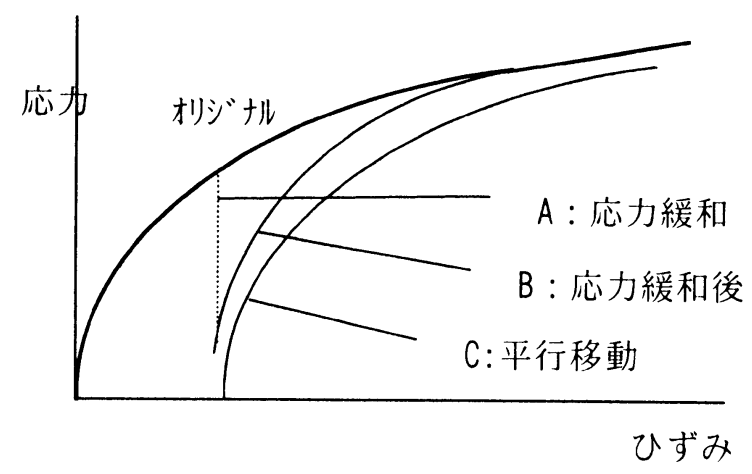

図8 応力ひずみ曲線形状 


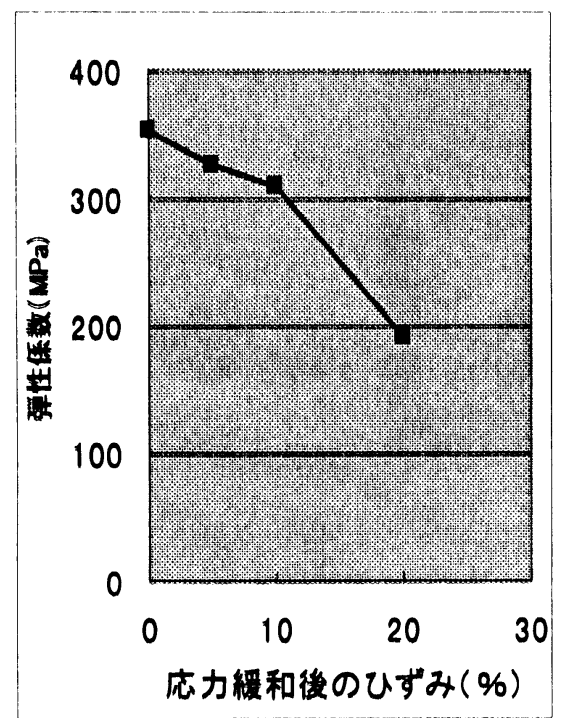

(HDPE シート)

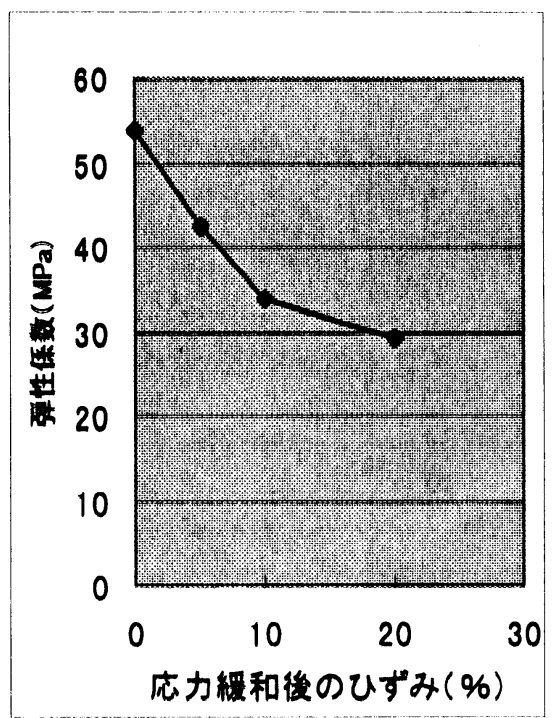

(FPA シート)

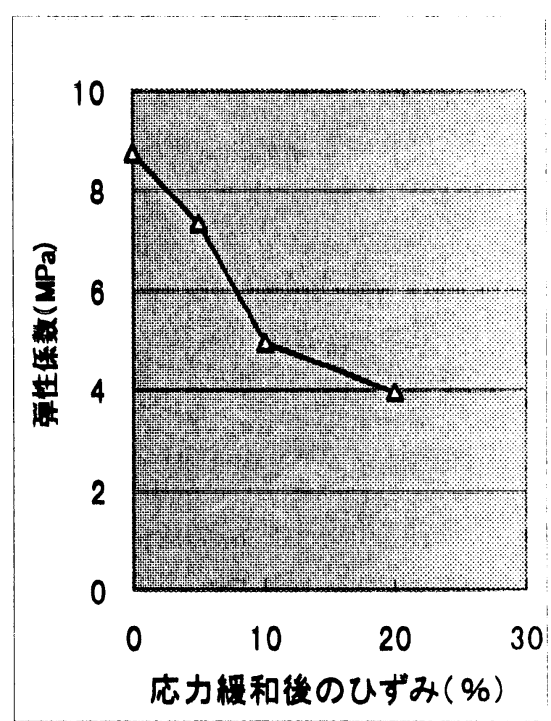

(EPDM シート)

図9応力綬和後の弾性係数の变化

図 9 より、ひずみ量が5\%、10\%、20\%と增加するほど応力緩和後の弾性係数は減少している。ま た、ジオメンブレンの弾性係数の絶対值については、従来は正方形の供試体を用いているが、本実験では JISで定めるダンベル形状としたために、若下小さな数値となっている。

応力変化後のジオメンブレンの応力は HDPE シートではひずみが約 $20 \%$ 程度で、FPA シートや EPDM シ 一トではひずみが $30 〜 40 \%$ 程度でほぼ一致している。したがって、ひずみ量の大きい領域ではほぼ同 一の曲線を示すものと考えられる。

\section{4.まとめ}

本実験から以下のような知見が得られた。

(1) ジオメンブレンの定ひずみ下の応力は時間の対数と直線関係を示した。

（2）ジオメンブレンの種類によって、応力緩和の傾向が異なる。HDPE シートでは応力が 24 時間後に半 分以下になるが、EPDM シートでは低下が少ない。FPA シ一トは中間的な結果を示した。

（3）応力緩和後の応力ひずみ曲線は、HDPE シートではひずみ約 $20 \%$ 、FPA シート及び EPDM シ一トでは ひずみ $30 \sim 40 \%$ 程度で㐫力緩和を受ける前の曲線と一致する。すなわち、ひずみ量が大きい領域 では応力緩和の影響は無視できるが、ひずみ量が小さい領域では大きな差があるといえる。

（4）応力緩和後の $1 \%$ 割線弾性係数は応力緩和を受ける前の弾性係数に比較して小さく、忍力緩和を受け るひずみ量が大きいほど減少する倾们を示した。 
最終処分場の法面や底面に敷設されたジオメンブレンに、地盤の変形等の影響を受けることからひずみ が発生するとき、ジオメンブレンには応力が発生するが、その後応力緩和にて応力は減少する。しかしな がらその後、さらにひずみが加わると、ひずみを受ける前の弾性係数に匹敵する応力が発生し最終的には ひずみを受ける前の応力ひずみ曲線と一致することから、応力緩和として応力の減少を見込むことは可能 であるが、断続的または継続的にひずみが進行する場合においては、応力緩和を見込むことは応力の過小 評価となる可能性があることから危険であると考えられる。

\section{（参考文献）}

1)廃棄物処分場における合成綫維利用技術開発報告書、（社）産業環境管理協会

2）鈴木茂、ゼオンシート、ジオシンセティックス技術情報 ‘97、Vol13、No.1、Pp.39-44

3）最終処分場技術システム研究会 しゃ水工設計ワーキンクグループ、表面しゃ水工設計手法に関する研究平成 8 年 度報告書

4）宮地秀樹・坪井正行・今泉繁良: 温度変化が各種ジオメンフレンの引つ張り特性に与える影響、第 11 回ジオシ ンセティックシンポジウム

5）坪井正行：土居洋一・野本哲也・今泉繁良・宮地秀樹：しゃ水シートの熱応力屋外実験、第 8 廃棄物学会研究発 表会講演集 